\title{
Features and Impacts of Second Homes Expansion: the Case of the Oeste Region, Portugal
}

\author{
Maria de Nazaré Oliveira Roca, Zoran Roca, \\ José António Oliveira
}

\begin{abstract}
In Portugal, the expansion of second homes has been an important feature of land use and landscape change. The growing omnipresence of second homes and the inherent environmental, economic, cultural and other aspects of land use are frequent discussion topics nowadays among policy- and opinion-makers, but this phenomenon has not yet become part of the national research agenda. In order to fill this gap, a research project entitled "SEGREX - Second Home Expansion and Spatial Development Planning in Portugal" was launched. The first phase of the project's fieldwork consisted of interviewing local authorities in the Oeste - the case-study region. Its aim was to identify localities with presence and/or growth of second homes, to determine the main features of second home expansion and to learn more about its economic, social, cultural and environmental impacts. Some findings are presented and discussed in this paper
\end{abstract}

Key words: second homes, tourism, peri-urban fringe, population mobility, Portugal

\section{Osobine i utjecaji rasta sekundarnog stanovanja u Portugalu: primjer regije Oeste}

U Portugalu je rast sekundarnog stanovanja postao važan čimbenik načina iskorištavanja zemljišta i promjene krajolika. Prostorna rasprostranjenost objekata te vrste stanovanja i s time povezani ekološki, ekonomski, kulturni i drugi aspekti iskorištavanja zemljišta česta su tema medijskih i političkih rasprava, ali nedostaju znanstvene obrade tog fenomena. Tu prazninu nastoji popuniti istraživački projekt ,SEGREX - Rast sekundarnog stanovanja i planiranje prostornog razvoja u Portugalu". Prva faza terenskog dijela istraživanja bilo je anketiranje ključnih predstavnika lokalnih vlasti u regiji Oeste, u kojoj je sekundarno stanovanje posebno izraženo. Ciljevi anketiranja bili su identificirati lokalitete na kojima već postoji i/ili jako raste fenomen sekundarnog stanovanja, utvrditi glavne značajke tog rasta te spoznati njegove utjecaje na lokalno gospodarstvo, društvo, kulturu i prirodni okoliš. Rad donosi prikaz rezultata tog istraživanja i raspravu o njima.

Ključne riječi: sekundarno stanovanje, turizam, prigradska područja, pokretljivost stanovništva, Portugal

Please cite this article as: Roca, M. N., Roca, Z., Oliveira, J. A., 2011: Features and Impacts of Second Homes Expansion: the Case of the Oeste Region, Portugal, Hrvatski geografski glasnik 73(2), 111-128 


\section{INTRODUCTION}

It is commonly agreed that the European rural space has been transformed from an agriculturally productivist to a post-productivist one, where agriculture has lost its land use hegemony and competes with other rural and non-rural activities. Agriculture became more extensive, less important and has assumed, besides production, environmental (e.g., land conservation, fostering of water resources) and socio-cultural roles (e.g., maintenance of cultural landscapes and heritage) (Roca, 2010; Müller, 2002; Müller et al., 2004; Ilbery and Bowler, 1998). Such rural changes are also due to the increasing penetration of urbanities through city people who, temporarily or permanently, consume the countryside for tourism and leisure, thus reinforcing urban lifestyles and the transfer of the rural-born population from agricultural to non-agricultural income generation activities, adopting along this process urban lifestyles through direct (e.g., rural-urban daily commuting) or indirect urban contact (e.g., the mass media).

Furthermore, in the productivist era ruralities penetrated directly into the urban milieu through rural to urban migration, while they have become indirectly present through the longing of the urbanites for an idealized "rural idyll" (Murdoch and Marsden, 1994; Clocke et al., 1998; Gorton et al., 1998) that is vanishing due to their own consumption of the rural space for urban land uses, such as second homes, physical infrastructures (e.g. highways, waste management), recreational and tourism facilities, and shopping centres and retail outlets.

Second homes have been an important cause and effect of the penetration of urbanities into the countryside. Some authors consider them an important element of counterurbanisation since second home ownership is frequently seen as the first step urbanites take in the decision-making process of moving permanently to the countryside (Müller, 1999, in Müller et al., 2004; Robinson, 1990 in Paris, 2006; Buller and Hoggart, 1994 in Leal, 2006). However, contrary to these authors, Leal (2006) and Selwood and Tonts (2004) assume that second homes are a substitute for counter-urbanisation and are caused by similar factors.

The use of second homes is generally seen as an expression of modern lifestyles based on the fruition of time for leisure and recreation and has been a constitutive element of land use change and new forms of spatial organization (Colás and Cabrerizo, 2004; Van Eetvelde and Antrop, 2004). Butler (1998) calls attention to the fact that changes in the recreationmotivated consumption of the rural space can be considered as having been a major trend in the restructuring of rural-urban relations since the 1960s. While this phenomenon has already evolved in countries such as the United Kingdom, Sweden and France, where the so-called "social tourism" policies were defined earlier (Coppock, 1977; Wolfe, 1962), it has been synonymous in most other countries to the Weblenian model (Peng, 2006) that explains the process of formation of the leisure class.

In turn, Müller (2004) explains that second homes represent a new dimension of the increasing complexity of contemporary mobility patterns, since second homes ever more challenge the actual (and commonly accepted) concept of a single "home" and corresponding public services associated with the place of residence. 
In other words, the second home can have a wide range of uses, from alternating first and second homes without any change in the time available beyond all livelihood chores up to exclusive use for leisure and recreation (Ericsson, Arnesen \& Overvåg, 2005).

In Portugal, the expansion of second homes has been an important feature of land use and landscape change. In the $1991-2001$ period, their number increased $40 \%$ (the number of first home dwellings grew only 16\%), so that 929936 second homes in 2001 represented $20 \%$ of all dwellings. The presence of second homes has been evident in diverse parts of the country - from the highly urbanized and dynamic coast to the aged and stagnating rural interior - especially in areas with attractive natural and cultural landscapes and other amenities. As in other Southern European countries, second homes in Portugal have a greater share in the housing stock than in other parts of Europe. For instance, according to Leal (2006) and Casado-Diaz (2004), in Spain they represent $27 \%$, in France 9\%, in the Netherlands $5 \%$, and in the UK and Germany $10 \%$ of the housing stock.

Recent spatial and sectorial development policy agendas have been marked by the growing importance of second homes in Portuguese tourism. However, the impacts of second home expansion have been perceived quite differently. For example, in the National Strategic Plan for Tourism (Plano Estratégico Nacional de Turismo - PENT), residential tourism is considered as one of the top-ten priorities to be promoted, while in the National Programme for Spatial Planning Policy (Programa Nacional de Política de Ordenamento do Território - PNPOT) it is recommended to control its expansion because of the effects it can have on the sustainability and management of land use and landscapes. The problem is that such policy statements have not been based on solid scientific understanding of this phenomenon. Only few local field studies on second homes in rural and coastal resort areas were carried out in the 1980s and 1990s, ${ }^{1}$ but no research on this subject was ever undertaken at regional and national levels. In fact, the growing omnipresence of second homes and the inherent environmental, economic, cultural and other aspects of land use conflicts and/or synergies are nowadays frequent discussion topics among policy- and opinion-makers, especially in the mass media, but this phenomenon has not yet become part of the national research agenda in Portugal.

In order to lfill this gap, a research project entitled "SEGREX - Second Home Expansion and Spatial Development Planning in Portugal", financed by the Portuguese Fund for Science and Technology, was launched in 2008. This has been the first and, so far, the only comprehensive research endeavour that explicitly deals with the issue of second home expansion and its impacts on spatial development at the national and regional levels. The working definition of "second home" adopted in the project is the one of the Portuguese Population and Housing Census: "Classical family dwellings of seasonal or secondary occupancy where no family member lives permanently".

The first phase of the SEGREX project, mostly based on macroscopic (desk) research and completed in 2009, resulted in a first-ever taxonomic classification of spatial types of second homes at national level, i.e., second homes in (i) the peri-urban fringe, (ii) the adjacent countryside, (iii) the depopulated countryside, (iv) the natural and cultural amenities rich countryside, (v) the summer vacation areas and resorts and (vi) the traditional tourism destinations of the Lisbon Metropolitan Area (Roca et al., 2010). 
The real challenge, however, has been to encompass locating second homes and recording the features and impacts of their expansion at the intra-regional and intramunicipal levels and, ultimately, to reach and characterize the second homes owners, as well as developers and promoters. Attempts in this direction were made in the second phase (field research) of the SEGREX project. Some findings are presented and discussed hereunder.

\section{RECORDING SECOND HOMES EXPANSION AT LOCAL LEVEL}

Since late 2009, field research has been carried on in the Oeste Region (a NUTS III, NW of the Lisbon Metropolitan Area) as an in-depth case-study aimed at attaining the following objectives: (i) drawing upon the findings from the desk study, to compare and characterize the phenomenon of second home expansion at regional level; (ii) to determine the structural driving forces and the effects of second home expansion; (iii) to identify place-specific driving forces, as well as spatial and socio-economic effects of second home expansion, and (iv) to provide an insight regarding the interrelations of second home expansion and spatial planning policies and development in the municipalities of the Oeste region.

The Oeste is a rural region in rapid change, in the area of influence of Lisbon, characterized by a diversified and dynamic economy marked by competitive agricultural production, numerous small and medium-sized firms in the agro-business and ceramics industry, and a rapidly rising tourism sector, particularly of second home tourism. As a matter of fact, according to the last Population and Housing Census, the share of second homes in the total number of dwellings in 2001 was $25 \%$ in the Region (20\% at national level) while their number grew $45 \%$ across the Region ( $40 \%$ at national level) between 1991 and 2001. In view of such high rate of growth, the Oeste has been considered, together with the Algarve, a priority region for the development of second home tourism in the National Strategic Plan for Tourism (Roca at al, 2010).

The first step of the fieldwork consisted of interviewing the leaders and other responsible staff of the Parish Councils (parish is the lowest territorial-administrative unit in Portugal) of the Oeste Region, with the following main objectives (i) to identify localities with strong presence and/or growth of second homes in order to obtain a sample of different types of second home owners, to be interviewed subsequently; (ii) to find out about the geographical origin of second home owners; (iii) to determine the frequency of use, location, type, state and age of construction of houses and types of households belonging to second home owners; (iv) to learn about the possible economic, social, cultural and environmental effects of second home expansion.

Until the end of 2010, interviews were held with representatives of more than a third (44) out of 121 Parish Councils, mostly located in the central and southern parts of the Oeste Region (Figure 1). The share of urban (25\%), rurban (45\%) and rural (29\%) ones among the covered parishes is quite similar to their share in the total number of parishes of the region $(21 \%, 48 \%, 31 \%$, respectively), thus guaranteeing the representative nature of the sample. 
Features and Impacts of Second Homes Expansion: the Case of the Oeste Region, Portugal

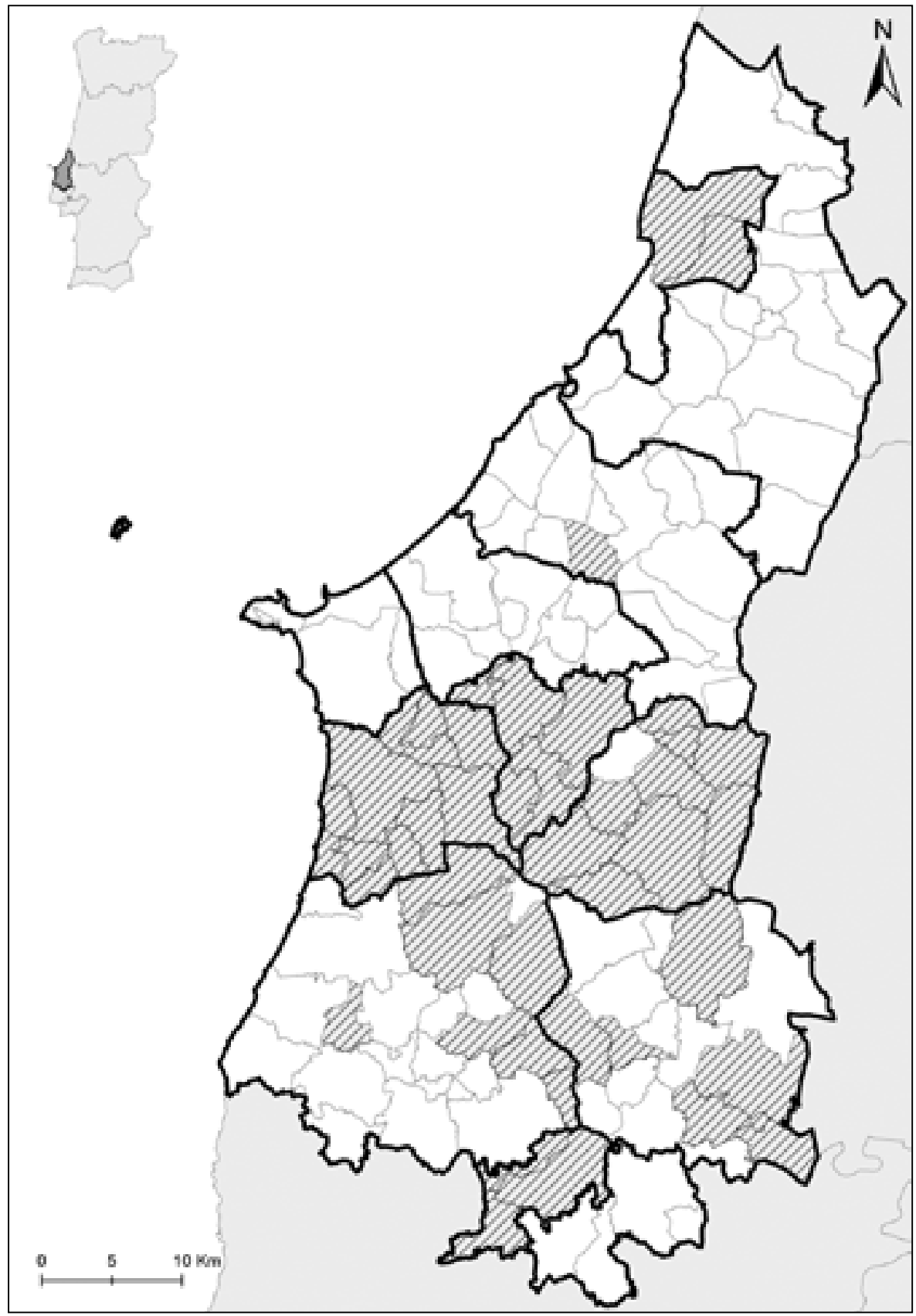

Fig. 1 Parishes covered by the interviews

Sl. 1. Župe obuhvaćene anketiranjem 

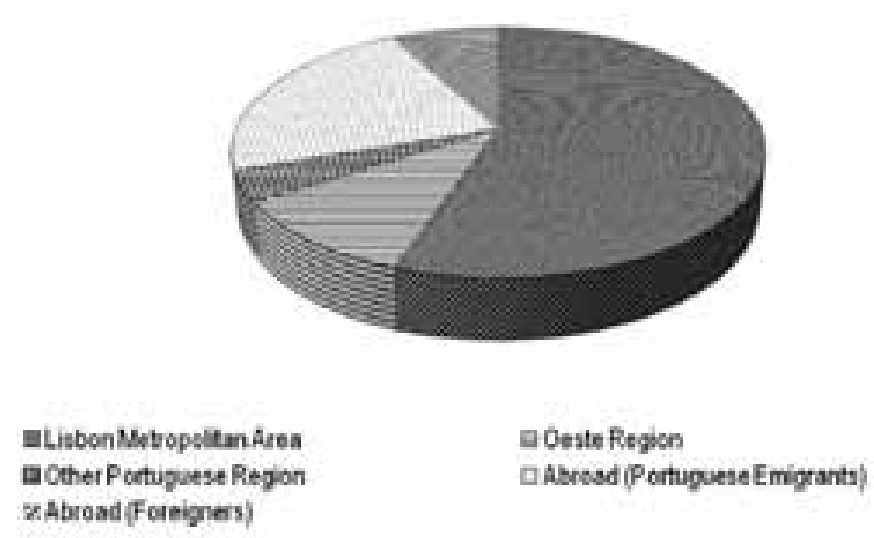

Fig. 2 Geographical origin of second home owners

Sl. 2. Geografsko podrijetlo vlasnika objekata za sekundarno stanovanje

According to the obtained responses, in the majority of 76 identified localities a strong presence and/or a rapid growth of second homes was registered, and permanent residents in the Lisbon Metropolitan Area (LMA) prevailed among the owners (figure 2).

The fieldwork area in the central and southern parts of the Oeste Region belongs to the peri-urban fringe of the LMA. In fact, peri-urban areas have been identified in many studies as major "consumption spaces" for second homes: within the weekend commuting distance from large urban centres, Jansson (1994, in Pettersson, 1999) identifies the 'weekend leisure space', Halseth and Rosenberg (1995) the 'rural-recreational countryside', and Lundgren (1974) the 'recreational hinterlands'. Likewise, Muller (2002) argues that many urbanites in Sweden choose the outskirts of the metropolitan areas for their second homes. The same holds for The Netherlands (Dijst et al., 2005). Also in Spain, CasadoDiaz (2004) highlights that almost two thirds of all tourist journeys are made by second home owners to places in the peri-urban fringe.

The following sections bring about findings from the analysis of second home owners from LMA only, since the other groups of second home owners (i.e., foreigners, Portuguese living abroad or in other regions) were too small to yield statistically significant results. Nevertheless, the other groups of owners are presented in the figures just for the sake of comparison with those from LMA.

First, the main socio-demographic and socio-economic features of second homes of owners from LMA are analysed. Then the opinions of the representatives of the Parish Councils about the local impacts of second home expansion are discussed in the context of the literature review on the subject.

\section{SECOND HOMES OWNED BY LMA RESIDENTS}

The respondents revealed that the expansion of second homes owned by LMA residents has been "very strong", "strong" or "medium to strong" (26 out of 43 answers) 


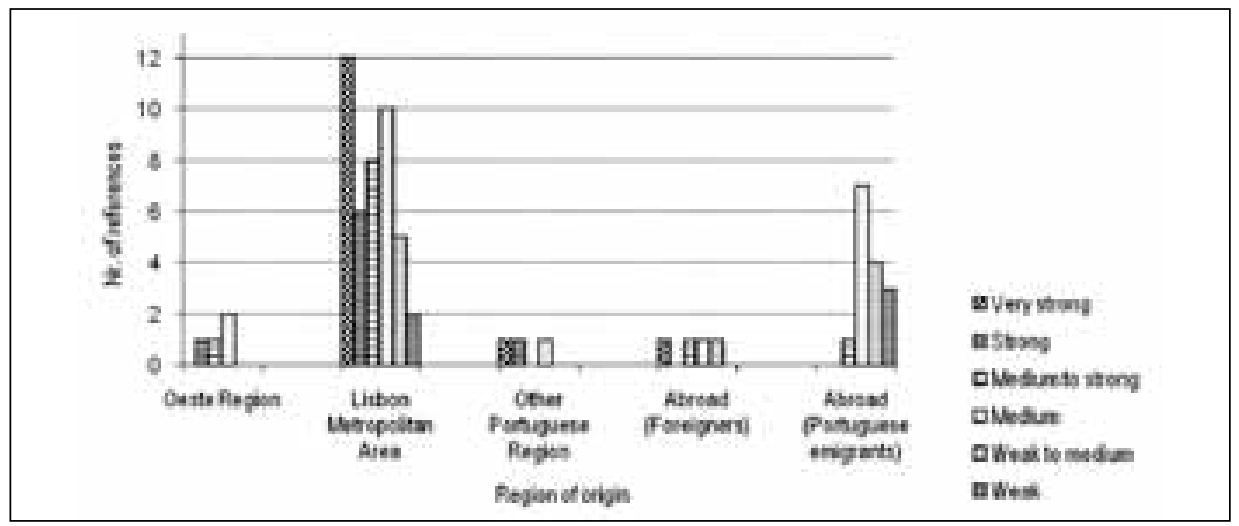

Fig. 3 Expansion of second homes by owners' origin

Sl. 3. Rast broja objekata sekundarnog stanovanja prema podrijetlu vlasnika

(Fig. 3). Such a trend can be interpreted as the result of a wide range of different factors, such as: increase in living standards of the population, including the generalised use of private automobiles and, related to that, the contemporary development of a Veblenian "leisure urban class" and of recreation-based lifestyles; intention of transforming the second home into primary home after retirement; the removal or inversion from everyday urban life; longing for the closeness to nature; the desire to spend time with the family; investment in real estate; controlled vacation expenses; enhancement of social status, in general (Hall and Müller, 2004:12-14; Quinn, 2004; Timothy, 2004 and Kaltenborn, 1998:123 in Quinn 2004), and, in particular, the significant decrease in travel-time and costs between the location of the second home and that of permanent residence in LMA, thanks to the expansion of the modern road network, thus improved accessibility. This makes it possible for LMA residents to stay in their second homes almost every weekend (Fig. 4). Such frequency is also possible because of the predominance of economically

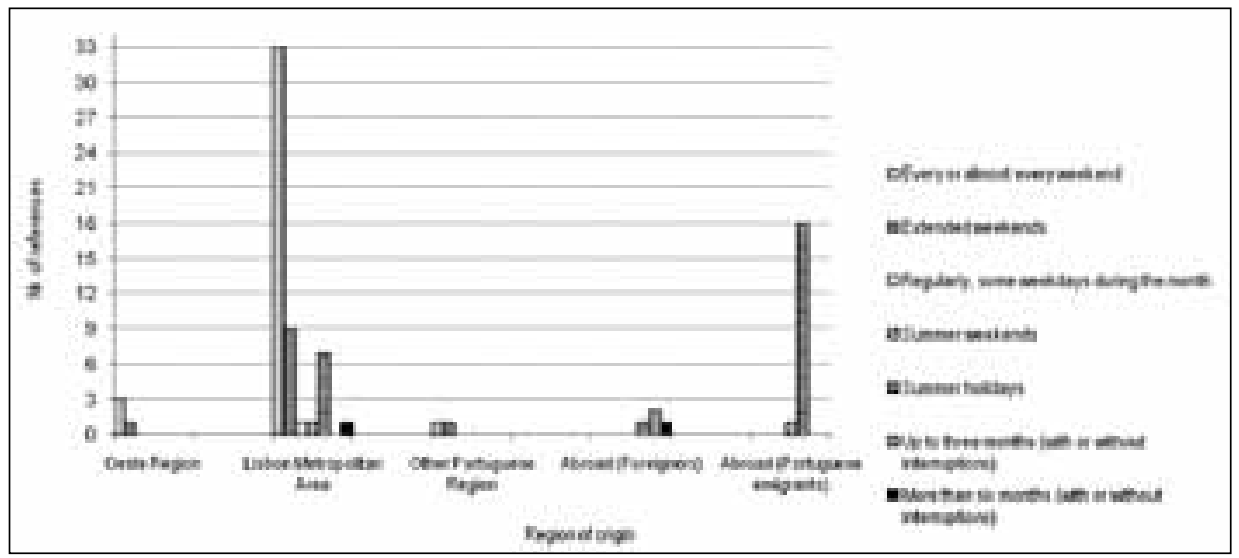

Fig. 4 Frequency of use of second homes by owners' origin

Sl. 4. Učestalost upotrebe objekata sekundarnog stanovanja prema podrijetlu vlasnika 


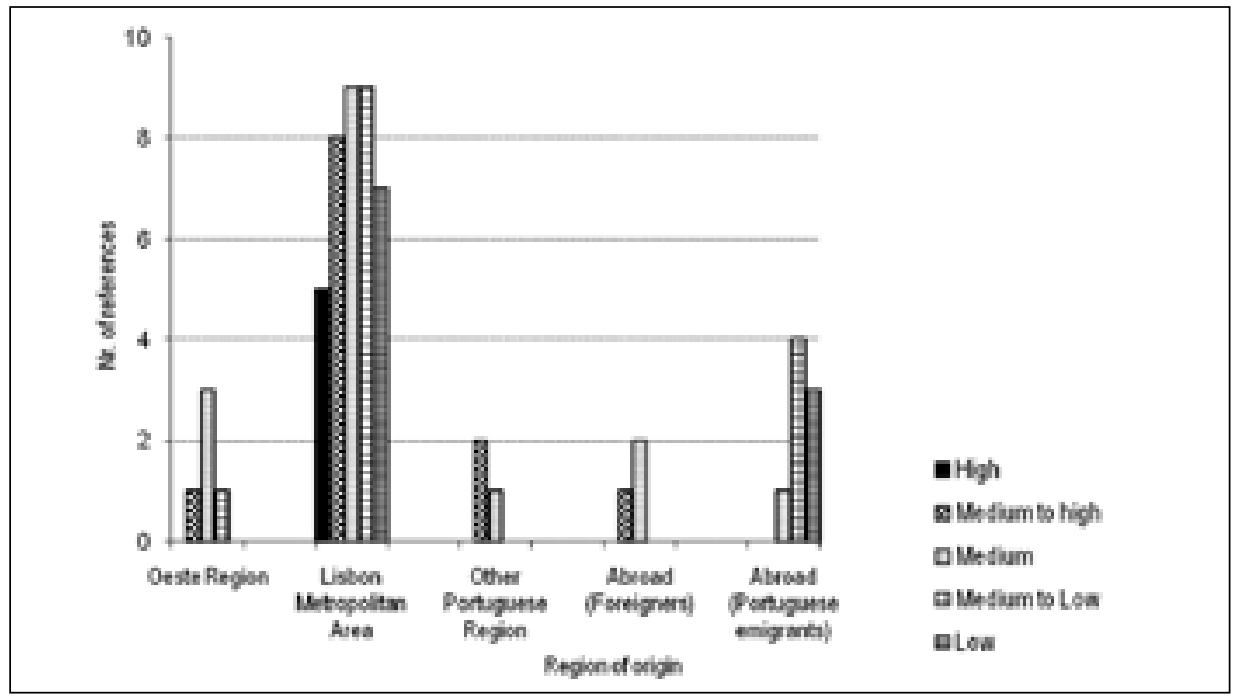

Fig. 5 Propensity to change the second into first home by owners' origin

Sl. 5. Sklonost vlasnika prema promjeni sekundarnoga u primarno stanovanje prema podrijetlu vlasnika

still active population among second home owners, whose leisure time predominantly is over the weekends. Thus, in the case of the Oeste Region, the alternative use of first and second homes for work rather than for leisure and recreation, as put forward by Ericsson (2006), seems to be still quite incipient.

The representatives of Parish Councils believe that second home owners from LMA have a "medium", "medium to low" or "low" (25 out of 38 answers) propensity to_change the second into the first home (Fig. 5). Such responses have to do with the prevailing family structure of this type of second home owners, that is, economically active couples with children of school age, as well as old couples with strong family ties in their place of residence Fig. 6). The low level of propensity to change second into first homes can also be related to push factors in the Oeste Region, for example, to the fact that there are still few alternative higher income employment opportunities that would suit the more educated second home owners. Thus, it seems that at this stage, the strong expansion of second homes in the Oeste Region is a result of growing rural gentrification (Hoogendoorn and Visser, 2004) rather than of the first stage of urban sprawl. In the near future, however, the propensity to change the second into the first home is likely to be higher when the "baby-boomers" start to retire.

The majority of LMA residents prefer to buy second homes that are located either in or outside rural agglomerations (36 out of 53 answers), and preferably individual houses, rather than in urban areas (17 answers) (Fig. 7). Thus, second homes are dispersed in the peri-urban space. In recent years, however, they tend to be more concentrated because most of the Municipal Master Plans that regulate urban land use, including second housing, became effective in the 1990s. This tendency is reflected in the fact that terraced houses 


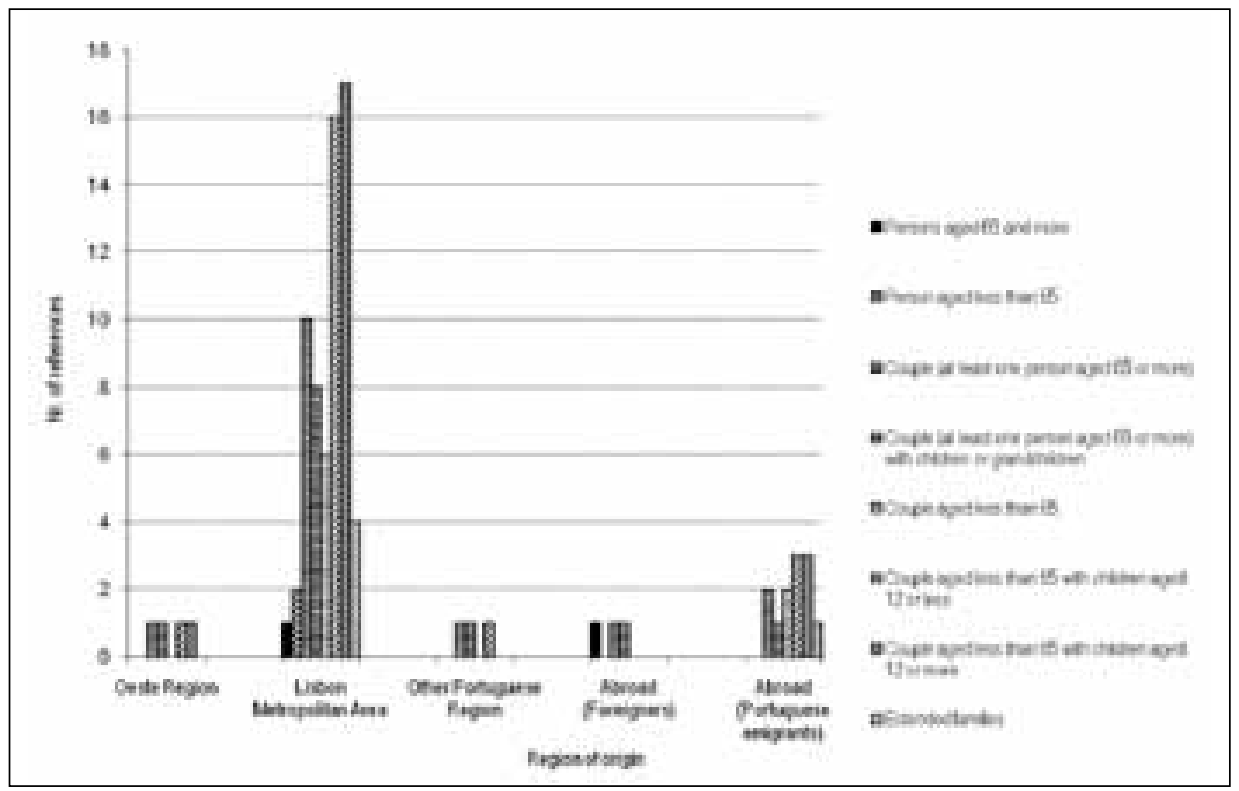

Fig. 6 Types of households of second home owners by their origin

Sl. 6. Vrste kućanstava vlasnika objekata sekundarnog stanovanja prema podrijetlu vlasnika

in the countryside are the second most frequent type of location. However, the presence of gated communities in the rural areas has still been quite rare, so thus the probability of rural landscapes becoming "elite landscapes" (Halseth, 1998) in the Oeste Region remains remote. The exceptions to this are the tourist resorts offering second homes, which are mainly located on the coastal settlements. (These areas will be closely studied in the forthcoming stage of the field research).

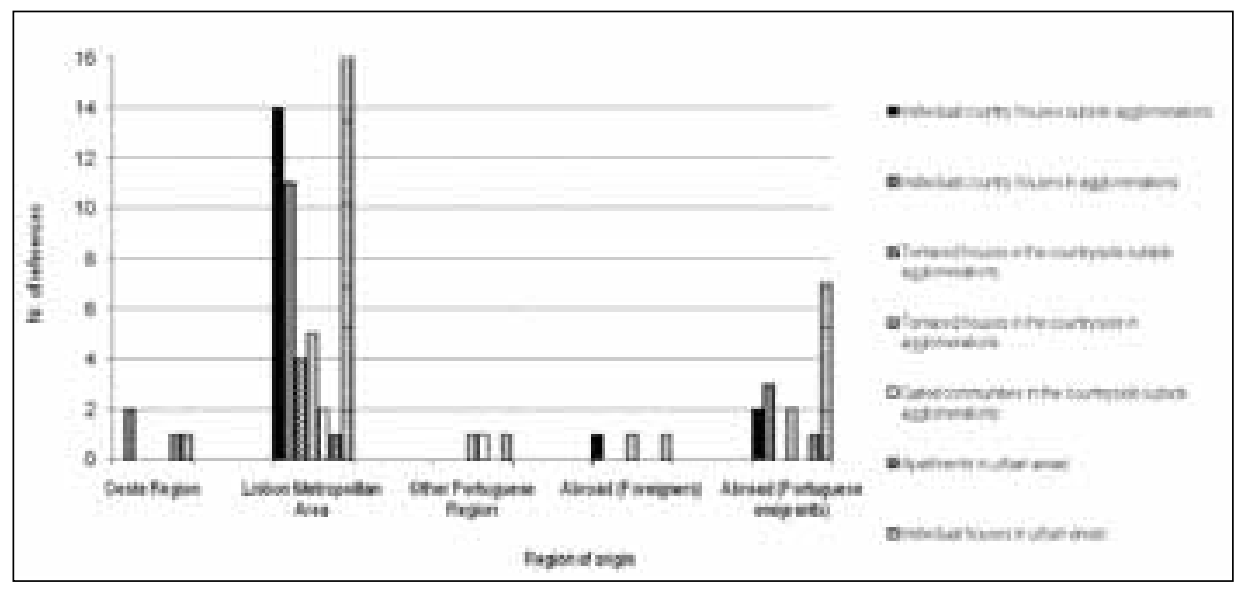

Fig. 7 Location of second homes by owners' origin

Sl. 7. Lokacija objekata sekundarnog stanovanja prema podrijetlu vlasnika 


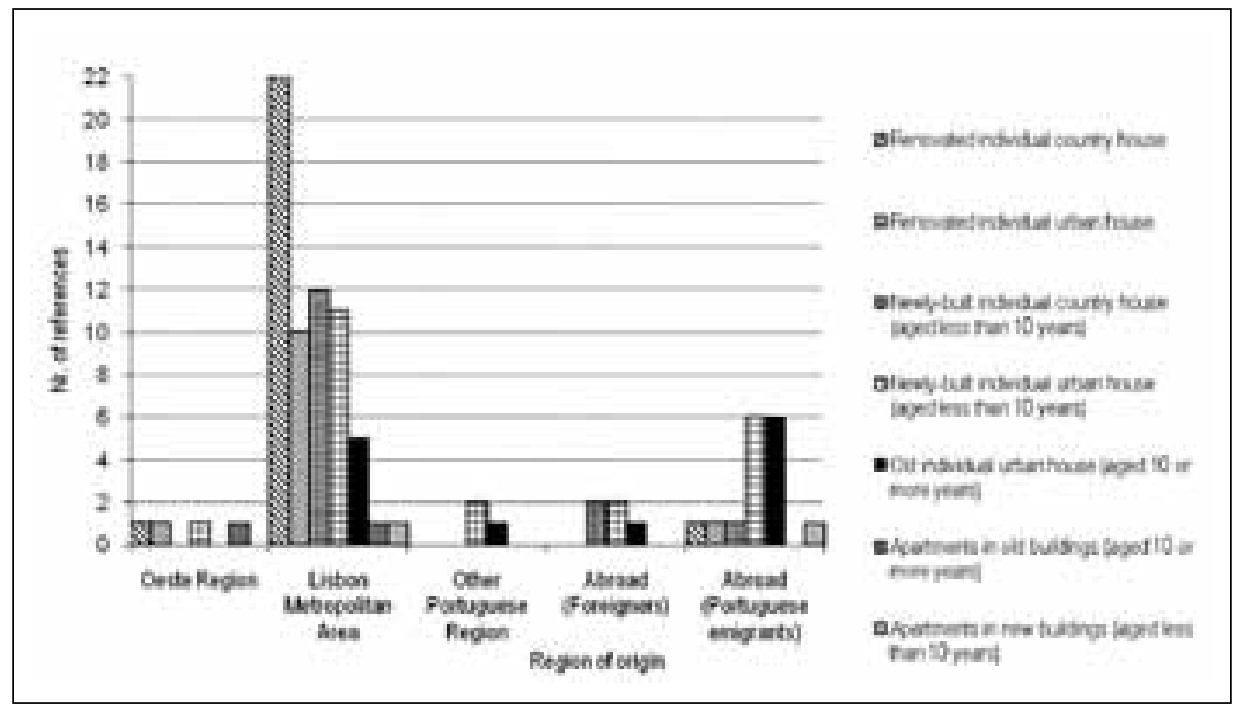

Fig. 8 Construction age and state of second homes

Sl. 8 . Vrijeme gradnje i stanje objekata sekundarnog stanovanja

In the opinion of the representatives of the Parish Councils, second home owners from LMA prefer to buy old houses and have them renovated (32 out of 62 answers), rather than to purchase newly-built ones (12 answers) (Fig. 8). In fact, a vast literature has shown the important role of second home owners in the preservation of the built heritage of villages and hamlets. In Portugal, field research in the Lousã Mountain conducted by Mendonça (1999-2000) and by Dinis and Malta (2001) and in the rural municipality of Trancoso by Carvalho (2003) identified second home owners as the most important type of residents accountable for housing renewal.

\section{THE IMPACTS OF SECOND HOME EXPANSION}

The representatives of the Parish Councils were also asked to give their opinions about the environmental, social, economic and cultural impacts of second home expansion on the localities they identified as marked by the presence of this phenomenon (Fig. 9 and 10). ${ }^{2}$ Most replied that impacts are positive while "no answer/does not know" ranked second in all categories, except in environmental impacts in rural areas where the neutral answer took this position. On the other hand, negative impacts were rarely mentioned by the interviewees.

According to Gallent and Tewdwr-Jones (2000: 51) the impacts of second home growth are "particularly linked to the types of dwelling used to this purpose". Since most of the second homes in the parishes covered by the sample belong to the type of housing stock classified by these authors as "derelict and empty surplus dwellings", that is, old country houses, their expansion provokes much less negative impact than the other two types: new-build and mainstream housing stock. 


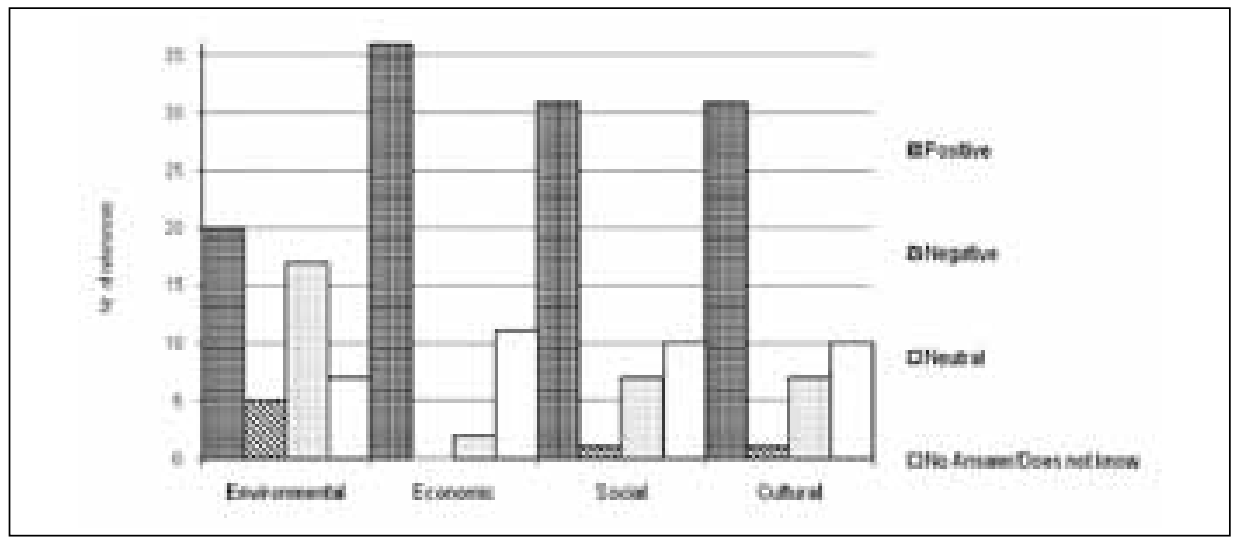

Fig. 9 Impacts of second homes located in rural areas

Sl. 9. Utjecaji sekundarnog stanovanja u ruralnim područjima

\section{Environmental impacts}

Concerning the positive environmental impacts of second homes, the predominant answer was "enhancement of civil responsibility and of environmental education" (13 out of 49 answers). In this respect, Muller et al (2004) argue that second home owners are more environmentally friendly compared to other rural development stakeholders. Also Jones et al (2003 in McIntyre et al., 2006: 243) "provided evidence to suggest that second home owners are environmentally better informed and educated than the local population". Correspondingly, Buller and Hoggart (1999, in Müller, 2004:22) stress that second home owners follow a "museum-strategy" of local development, that is, they aim to preserve the countryside as an artefact, while local people choose the "home-strategy", i.e., they wish to develop the countryside without alienating its single elements.

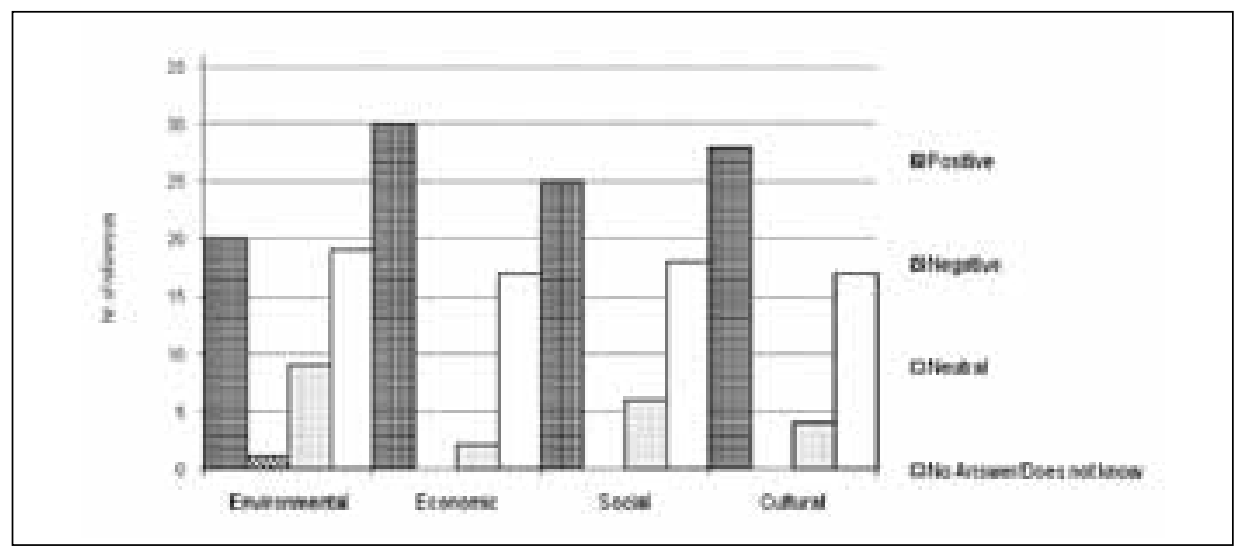

Fig. 10 Impacts of second homes located in urban areas

Sl. 10. Utjecaji sekundarnog stanovanja u urbanim područjima 
Other positive environmental impact frequently mentioned was the "renewing, recovery and maintenance of old country houses" (11). Indeed, as Hoggart and Buller (1995, in Gallent and Tewdwr-Jones, 2000:50) found out, "conversion may offer positive environmental benefits as restoration and change of use can lead to the preservation of derelict properties on the verge of being demolished". Also Pyne (1973, in Gallent and Tewdwr-Jones, 2000:50) argued that renovation contributes to the visual character of the surrounding areas.

On the other hand, besides the response "none, or does not know" (25) the following negative environmental impacts were identified: "consumption standards that strain the environmental carrying capacity (pollution, waste, water, etc.)" (12) and "increasing costs of the use and improvement of physical infra-structures" (8). Similar findings were reported by Stroud (1985), Vasievich (1999) and Muller et al., (2004).

\section{Economic impacts}

Among the positive economic impacts, the following were the most frequent: "stronger local market and increase in consumption of local and regional products" (22), "creation of firms and employment generation" (10) and "improvement of social and physical infra-structures" (8). In fact, as Gallent et al. (2005:55) claim, second homes provide a flow of money supporting local economy. Other authors also point out that with longer stays, second home owners will more frequently purchase locally available consumable goods (Jacobs, 1972; Archer, 1973; Clout, 1972 in Gallent et al., 2005:55). Likewise, in a literature review, Paris (2006: 7) argues that many second home owners favour expenditure within the local economy of their second home. However, for Gallent et al. (2005:58) the positive economic impacts exceed the negative ones only in areas where the "derelict and empty surplus dwelling" type of housing stock prevails and thus, the displacement of local residents is less probable to occur.

\section{Social impacts}

"Interaction with and integration into the local community, stronger neighbourhood ties and civil participation" (35) accounted for almost all positive social impacts pointed out by the interviewees. This provides evidence that second home owners can also show a strong attachment to the place. Stewart and Stynes (2006) doing field research in the US Midwest and Stedman (2006) in Northern Wisconsin came to a similar conclusion. This could be expected since, as Muller (2000) points out, second home owners visit their second home regularly and are thus closely attached to the second home area. Others may have family links to the place of the second home (Kaltenborn, 1997).

Indeed, as Gustafson (2006: 19) stresses, "notions such as 'second home' and 'multiple dwelling' imply that a person's attachment is not necessarily limited to one single home place". However, Wall (1997, in Muller, 2000:7) notes that"with concern to the tight place attachment of many second home owners, it is, however, important to ask after how many years a second home owner has to be considered a legitimate part of the local community and who is the legitimate party to decide on this question". 


\section{Cultural impacts}

The opinions on the positive cultural impacts were the most diversified: "increased participation in social activities and cultural events" (11); "intensification of cultural activities, especially creation of cultural associations and groups" (11); "restoring the built heritage" (7); and, "multicultural milieu and exchange of experiences" (6). These answers can partly find an explanation in Stoa's assertion (2007:10) that "many second home owners lead a more active social life in the cottage village than they do in their urban home because working days tend to be too busy". On the other hand, Dinis and Malta (2001) and Carvalho (2003) reported from their research on the mountainous area of Lousã, Central Portugal, that second home owners keep fragile links with the permanent, mostly old local population.

As was already mentioned, a vast majority of interviewees answered "none, or does not know" when asked about the negative economic (36 out of 49), social (23) and cultural (34) impacts of second home expansion.

\section{IN LIEU OF CONCLUSION}

The most outstanding features of second homes owned by LMA residents can be summarized as follows: (i) the expansion of this phenomenon has been quite strong; (ii) the owners spend almost every weekend in the second homes; (iii) because most of the households consist of couples of active age with young children, the propensity to change the second to the first home is likely to be low in the near future; and (iv) most second home owners prefer to live in renovated old individual country houses.

These features can partly explain why positive impacts of second home expansion in the area covered by the survey clearly outstrip the negative ones, particularly the fact that most of the houses for second home use are drawn from the derelict and empty surplus housing stock, as referred to by Gallent et al. (2005). Also, this interior area is characterized by being predominantly rural with a declining and aged, mostly agricultural population. Thus, the local authorities can easily perceive the impacts of such phenomenon as mostly positive, since they seek for external forces that could compensate such negative demographic trends. Property tax revenues from second homes, which are collected exclusively by local governments, are a good example.

However, it is expected that, as the survey covers more urban and coastal parishes in which the concentration and expansion of second homes is higher, their negative impacts will gain importance. Indeed, it came out from field observation that such impacts are already visible, for example: silting of lagoons and rivers; coastal erosion; increasing pressure on sewage systems and water consumption; inflating property prices; and, the existence of the so-called "ghost" towns where during weekdays or the winter, most houses are empty and retail shops and services closed.

Thus, it seems that in the case of the Oeste Region the dilemma "second homes: a curse or blessing?" launched by Coppock (1977) could not be answered straightforwardly because of the dichotomic nature of impacts of their expansion regarding urban and/or coastal areas on the one hand and, on the other, rural parts of the region. Further research, 
in the remaining phases of the SEGREX project should shed more light on this dilemma, and will probably open new ones regarding spatial planning and territorial development strategies at local and regional levels.

\section{NOTES}

1 Apart from the pioneering work by Cavaco (1981), which refers to second homes in Cascais but was not the main concern of her study, it is worth mentioning: Cravidão (1989, 1989a) and Dinis and Malta (2001), who studied the elites of Coimbra as second home owners in the mountain area of Lousã in Central Portugal; Santos (1993) and Sampaio (1999-2000) who studied holiday resorts; Caldeira (1995) and Castelo and Ferreira (1988) who explored the phenomenon of second homes in the Lisbon Metropolitan Area; and, Mendonça (1999-2000) who investigated a depopulated area of Central Portugal.

2 Drawing on the four key components of territorial identity features, as suggested in the Identerra Model (Roca and Roca, 2007; Oliveira et al., 2010), the following hypothetical range of impacts were presented to the interviewees: (i) environmental impacts - use of sanitation infrastructure, protection of flora and fauna, water and electricity consumption, wastewater treatment, solid waste collection and treatment; (ii) economic impacts - job creation, management of the urban and rural economy, use of social infrastructure, use of health services, road infrastructure, local commerce, products of local handicrafts, housing renewal, quality of life, tourism demand, consumption of local products, agricultural activity, municipal expenses and revenues; (iii) social impacts - neighborhood relations, citizens' participation in public life, social life, provision of public services, provision of recreation and entertainment, interaction with local residents, security, crime, rejuvenation of the population, aging of the population; (iv) cultural impacts - architectural styles, gardening style, local identity, revival of the historic centres, cultural innovations, preservation of the rural and urban landscapes, provision of cultural services, cultural and recreational events, beauty of the urban landscape; and, beauty of the countryside.

\section{REFERENCES}

Archer, B., 1973: The Impact of Domestic Tourism, Bangor Occasional Papers in Economics 2, Bangor, University of Wales Press.

Buller, H., Hoggart, K., 1994: International counter-urbanization: British migrants in rural France, Aldershot, Ashgate.

Butler, R., 1998: Rural recreation and tourism, in: The Geography of Rural Change (ed. Ilbery, B.), Longman, Harlow, 211-232.

Caldeira, M. J., 1995: Residência secundária na Área Metropolitana de Lisboa-Outros espaços outras vivências, Faculdade de Letras da Universidade de Lisboa, photocopied.

Carvalho, P., 2003: População, território e desenvolvimento. Análise a partir das aldeias serranas da Lousã rede de aldeias do xisto. X Meeting of the Portuguese Association for Regional Development; Évora, June. (In CD-Rom)

Casado-Diaz, M. A., 2004: Second homes in Spain, in: Tourism, mobility and second homes: between elite landscape and common ground (eds. Hall, C. M., Müller, D. K.), Clevedon, Channel View Publications, 215-232.

Castelo, A., Ferreira, C., 1988: Segunda habitação em meio rural: Fontanelas, uma aldeia no concelho de Sintra, in: $1^{\circ}$ Colóquio Hispano-Português de Estudos Rurais; Évora. 
Features and Impacts of Second Homes Expansion: the Case of the Oeste Region, Portugal

Cavaco, C., 1981: A Costa do Estoril: Esboço Geográfico, CEG, Lisbon. Photocopied.

Cloke, P., Goodwin, M., Milbourne, P., 1998: Inside looking out; outside looking in. different experiences of cultural competence in rural lifestyles, in: Migration to rural areas (eds. Boyle, P., Halfacree, K.), Chichester: John Wiley \& Sons, 134-150.

Clout, H. D., 1973: "350,000 Second Homes, Geographical Magazine 45 (10), p. 750.

Colás, J. L., Cabrerizo, J. A., 2004: Vivienda secundaria y residencia múltiple en España: Una aproximación sociodemográfica, Geo Crítica/Scripta Nova, Revista Electrónica de Geografia y Ciencias Sociales [serial online]; 8(178), http://www.ub.es/geocrit/sn/sn-178.htm via the INTERNET. (3.2. 2011)

Coppock, J. T. (ed.), 1977: Second homes, Curse or Blessing, Pergamon Press, Oxford.

Cravidão, F. D., 1989: A residência secundária da burguesia de Coimbra - Projecto de Investigação, Cadernos de Geografia 8, Coimbra.

Dijst, M., Lanzendorf, M. and Smit, L., 2005: Second Homes in Germany and The Netherlands: Ownership and Travel Impact Explained, Tijdschrift voor Economische en Sociale Geografie 96 (2), 139-152.

Dinis, I., Malta, M., 2001: Da desvitalização à nova ruralidade: identidades e destinos do território na serra da Lousã, in: $1^{\circ}$ Congresso de Estudos Rurais; 2001 September 16-18; Vila Real. http://home.utad.pt/ des/ cer/cer/download/2009.pdf (21.4.2007)

Ericsson, B., 2006: Second homes in Norway: factors motivating for ownership and usage, with differing market perspectives and planning parameters, Scandinavian Journal of Hospitality and Tourism, 6.

Ericsson, B., Arnesen, T., Overvåg, K., 2005: Fra hyttefolk til sekundcerbosatte. Etforprosjekt. Østlandsforskning (ØFrapport), Lillehammer.

Gallent, N., Mace, A., Tewdwr-Jones, M., 2005: Second Homes - European Perspectives and UK Policies, Ashgate, London.

Gallent, N., Tewdwr-Jones, M., 2000: Rural Second Homes in Europe-Examining Housing Supply and Planning Control, Ashgate, London.

Gorton, M., White, J., Chaston, I., 1998: Counterurbanisation, Fragmentation and the Paradox of the Rural Idyll, John Wiley \& Sons, Chichester, 215-235.

Gustafson, P., 2006: Place Attachment and Mobility, in: Multiple Dwelling and Tourism - Negotiating Place, Home and Identity (eds. McIntyre, N., Williams, D., McHugh, K), Cabi, Cambridge, 17-31.

Hall, C. M., Müller, D. K., 2004: Introduction: second homes, curse or blessing? Revisited, in: Tourism, mobility and second homes: between elite landscape and common ground (eds. Hall C.M., Müller D.K.), Channel View Publications, Clevedon, 3-14.

Halseth, G., 1998: Cottage Country in Transition: a Social Geography of Change and Contention in the Rural Recreational Countryside, McGill-Queen's Press, Georgetown.

Halseth, G., Rosenberg, M. W., 1995: Cottagers in an urban field, Professional Geographer 47, 148-159.

Hoggart, K., Buller, H., 1995: British Home Owners and Housing Change in Rural France, Housing Studies $10(2), 179-198$.

Hoogendoorn, G., Visser, G., 2004: Second homes and small-town (re)development: the case of Clarens, Journal of Family Ecology and Consumer Sciences, 32, 105-115.

Ilbery, B., Bowler, I., 1998: From agricultural productivism to post-productivism, in: The Geography of Rural Change (ed. Ilbery B.), Longman, Harlow, 57-84.

Jacobs, C. A. J., 1972: Second Homes in Denbighshire, Ruthin, County of Dembigh Tourism and Recreation Report No. 3.

Jansson, B., 1994: Borta Bra Men Hemma Bäst: Svenskars Turistresor under Sommaren. (Umea: Geografiska Institutionen). 
Jones, R. E., Fly, J. M., Talley, M., Cordell, H. K., 2003: Green Migration into Rural America: The New Frontier of Environmentalists? Society and Natural Resources 16, 221-238.

Kaltenborn, B. P., 1997: The alternative home: motives of recreation home use, Norsk Geografisk Tidsskrift 52 (3), 121-134.

Leal, J., 2006: Multiple residential practices and second homes in southern Europe: the Spanish case. ENHR Conference - Housing in an expanding Europe: theory, policy, participation and implementation; 2006 July 2-5; Ljubljana. http://enhr2006-ljubljana.uirs.si/publish/W24_Leal.pdf via the INTERNET. (20.4.2007).

Lundgren, J. O. J., 1974: On access to recreational lands in dynamic metropolitan hinterlands, Tourist Review $29,124-131$.

McIntyre, N., Williams, D., McHugh, K., 2006: Multiple Dwelling and Tourism - Negotiating Place, Home and Identity, Cabi, Cambridge.

Mendonça, J. A., 1999-2000: Transformações socioeconómicas recentes no concelho de Tarouca, Revista da Faculdade de Letras - Geografia 15/16, 145-159.

Müeller, D. K., 2002: Reinventing the countryside: German second-home owners in southern Sweden, Current Issues in Tourism 5, 426-446.

Müller, D. K., 1999: German second home owners in the Swedish countryside: on the internationalization of the leisure space, Umeå: Kulturgeografiska institutionen.

Müller, D. K., 2004: Second homes in Sweden: patterns and issues. in: Tourism, mobility and second homes: between elite landscape and common ground (eds. Hall, C. M., Müller, D. K.), Channel View Publications, Clevedon, 244-258.

Müller, D. K., Hall, C. M., Keen, D., 2004: Second home tourism impact, planning and management, in: Tourism, mobility and second homes: between elite landscape and common ground (eds. Hall, C. M., Müller, D. K.), Channel View Publications, Clevedon, 15-32.

Müller, D. K., 2000: Second Home Tourism and Sustainable Development in North European Peripheries, $\mathrm{http} / /$ lab.geog.ntu.edu.tw/course/ginformation/hw/2003hw/chen/second $\% 20$ home $\% 20$ tourism $\% 20$ and $\% 20$ sustainable\%20development.pdf (3.2.2011)

Murdock, J., Marsden, T., 1994: Reconstituting Rurality, UCL Press, London.

Oliveira, J. A., Roca, Z, Leitão, N., 2010: Territorial Identity and Development: From Topophilia to Terraphilia, Land Use Policy 27 (3), 801-814.

Paris, C., 2006: Multiple "homes", dwelling \& hyper-mobility \& emergent transnational second home ownership, in: ENHR Conference - Housing in an expanding Europe: theory, policy, participation and implementation, Ljubljana, July 2-5. http://enhr2006-ljubljana.uirs.si/publish/W24_Paris.pdf. (20.4. 2007).

Peng, B., 2006: A Model of Veblenian Growth, Topics in Macroeconomics, 6 (1), Article 11. The Berkeley Electronic Press. http://www.bepress.com/bejm/topics/vol6/iss1/art11. (3.2.2011)

Pettersson, R., 1999: Foreign Second Home Purchases - The Case of Northern Sweden, 1990-96, CERUM Working Paper Nr. 14, Umeå: Umeå University.

Pyne, C. B., 1973: Second Homes, Caernarvonshire County Planning Department.

Quinn, B., 2004: Dwelling through multiple places: a case study of second home ownership in Ireland, in: Tourism, mobility and second homes: between elite landscape and common ground (eds. Hall, C. M., Müller, D. K.), Channel View Publications, Clevedon, 113-130.

Robinson, G., 1990: Conflict and change in the countryside, Belhaven Press, London.

Roca, M. N., Oliveira, A., Roca, Z., 2010: Seconda Casa e Turismo della Seconda Casa en Portogallo, in: Il Turismo Residenziale. Nuovi stili di vita e di residenzialità, governance del territorio e sviluppo sostenibile del turismo in Europa (ed. Romita, T.), Franco Angeli, Milano, 111-130.

Roca, Z. (2010): Landscape, Identity and Development, in: Landscape and Driving Forces, 8th meeting of the 
Features and Impacts of Second Homes Expansion: the Case of the Oeste Region, Portugal

Council of Europe workshops for the implementation of the European Landscape Convention, European Spatial Planning and Landscape, No. 93, Council of Europe Publishing, Strasbourg, 65-77.

Roca, Z., Roca, M. N. O., 2007: Affirmation of Territorial Identity: A Development Policy Issue, Land Use Policy 24 (2), 434-442.

Sampaio, J., 1999-2000: Considerações sobre a residência secundária em Esposende, Revista da Faculdade de Letras - Geografia: 15/16, 131-143.

Santos, M. G. P., 1993: A residência secundária no âmbito da geografia dos tempos livres, análise comparativa dos casos de São Pedro de Moel e Praia de Vieira, FLUC, Coimbra.

Selwoood, J., Tonts, M., 2004: Recreational second homes in the south west of Western Australia, in: Tourism, mobility and second homes: between elite landscape and common ground (eds. Hall, C. M., Müller, D. K.), Channel View Publications, Clevedon, 149-161.

Stedman, R. C., 2006: Places of Escape: Second-home Meanings in Northern Wisconsin, USA, in: Multiple Dwelling and Tourism - Negotiating Place, Home and Identity (eds. McIntyre, N., Williams, D., McHugh, K), Cabi, Cambridge, 129-144.

Stewart, S. I., Stynes, D. J., 2006: Second-homes in the Upper Midwest, in: Multiple Dwelling and TourismNegotiating Place, Home and Identity (eds. McIntyre, N., Williams, D., McHugh, K), Cabi, Cambridge, 180-193.

Stoa, E., 2007: Urban cottages - Rural homes? Changing Home Cultures: Challenges towards Sustainable Development, in: ENHR 2007 International Conference 'Sustainable Urban Areas ', Rotterdam, 25-28 June, http://www.enhr2007rotterdam.nl/documents/W15_paper_Stoa.pdf (3.2.2011)

Stroud, H., 1983: Environmental Problems Associated with Large Recreational Subdivisions, Professional Geographer 35 (3), 303-313.

Timothy, D. J., 2004: Recreational second homes in the United States: development issues and contemporary, in: Tourism, mobility and second homes: between elite landscape and common ground (eds. Hall, C. M., Müller, D. K.), Channel View Publications, Clevedon, 133-148.

Van Eetvelde, V., Antrop, M., 2004: Analyzing structural and functional changes of traditional landscapes: two examples from southern France, Landscape and Urban Planning 67 (1/4), 79-95.

Vasievich, M., 1999: Here Comes the Neighbourhood - A New Gold Rush and Eleven Other Trends Affecting the Midwest, NC News, North Central Forest Experimental Station, August/September.

Wall, G., (1997): Rethinking impacts of tourism, in: Tourism Development: Environmental and Community Issues (eds. Cooper, C., Wanhill, S.), Chichester: Wiley, 1-10.

Wolfe, R. I., 1962: The summer resorts of Ontario in the nineteenth century, Ontario History (54), 149-161.

Received (Primljeno): 2011 - 02 - 06

Accepted (Prihvaćeno): 2011 - 12- 19 
Hrvatski geografski glasnik 73/2 (2011.)

Maria de Nazaré Oliveira Roca

mn.roca@fcsh.unl.pt

Zoran Roca

Zoran.roca@ulusofona.pt

José António Oliveira

jantol@fnetcabo.pt 